\title{
Comparative morphometric traits differentiation and phenotypic correlations between Achatina achatina (Linne, 1758) and Achatina fulica (Bowdich, 1822) snails with four and five whorls
}

\author{
Okon, B. ${ }^{*}$ Ibom, L. A, Halilu A. and Onwuka, P. O. \\ Department of Animal Science, University of Calabar, Calabar, Nigeria. \\ *Corresponding author. Email: profbasseyokon@gmail.com. Tel: +234(0)803 4183263.
}

Copyright (@ 2017 Okon et al. This article remains permanently open access under the terms of the Creative Commons Attribution License 4.0, which permits unrestricted use, distribution, and reproduction in any medium, provided the original work is properly cited.

Received 25th March, 2017; Accepted 19th April, 2017

\begin{abstract}
Four hundred (400) adult black-skinned snails, two hundred (200) each of the Achatina achatina and Achatina fulica with 4 and 5 whorls were used respectively for the study. Identification and sorting of the snails sourced from a reputable snail vendor in Ibadan into breeds was done using the appropriate profile and template. The body weights of Achatina achatina and Achatina fulica snails with 4 whorls ranged from 83.00 to $180.50 \mathrm{~g}$ (average $156.90 \mathrm{~g}$ ) and from 30.60 to $85.20 \mathrm{~g}$ (average $49.70 \mathrm{~g}$ ) respectively. That for Achatina achatina and Achatina fulica snails with 5 whorls ranged from 132.70 to $272.80 \mathrm{~g}$ (average $138.95 \mathrm{~g}$ ) and from 50.60 to $119.30 \mathrm{~g}$ (average $59.58 \mathrm{~g}$ ) respectively. Results obtained from the study showed that Achatina achatina snails with 4 and 5 whorls were genetically heavier and larger than Achatina fulica with 4 and 5 whorls. Results of phenotypic correlation coefficient among morphometric traits of the two breeds indicated negative, weak, low significant $(P<0.05)$ and mostly non-significant $(P>0.05)$ differences between body weight and most body components (morphometric traits) studied. The only positive, low non-significant $(P>0.05)$ phenotypic correlation coefficient $\left(r_{p}\right)$ obtained was $r=0.420$ between body weight and aperture width for Achatina fulica snails with 4 whorls. Whereas, for Achatina achatina snails with 5 whorls, positive, low significant $(P<0.05)$ phenotypic correlation coefficients obtained was $r=0.529$ between body weight and aperture width and $r=$ 0.660 between spiral width and aperture width respectively. Achatina fulica snails recorded the only positive highly significant $(P<0.01)$ phenotypic correlation coefficient of $r=0.602$ between aperture width and shell width for the snails with 5 whorls. Breed type, age and size differences of snails used, body weight ranges, as well as number of whorls on snail shell have high effects of morphometric traits differentiation and phenotypic correlation coefficient estimates. Thus, the morphometric traits of the two breeds (Achatina achatina and Achatina fulica) of snails studied could be chosen to differentiate as well as characterize snails.
\end{abstract}

Key words: Black-skinned snails, Achatina achatina, Achatina fulica, morphometric traits, phenotypic correlations.

\section{INTRODUCTION}

Snail farming is an interesting and profitable venture if large, mature breeding stocks of snails with high reproductive potentials are used and properly managed. Nigeria is richly endowed with many breeds of snails (Archahatina marginata, Achatina achatina, Achatina fulica) which has recently attracted the attention of consumers, producers/sellers and researchers (Okon and Ibom, 2012; Nwankwo and Onwarah, 2015).
Among these, Achatina achatina and Achatina fulica are snails with tremendous unexploited nutritional, health, economic and genetical potentials. According to Okon et al. (2012), Achatina achatina is the largest gastropod among the giant African land snails recorded in the Guinness Book of records, with a maximum of recorded shell length of $27 \mathrm{~cm}$; while Achatina fulica is the smallest (CAB, 2003, Venette and Larson, 2004). But in Nigeria, 
Achatina achatina is the second most popular breed of snail after Archachatina marginata kept and reared (Okon et al., 2012).

Achatina achatina (Plate 1) also called giant Ghana snail or giant tiger land snail is found in Nigeria, Ghana, Cameron, Guinea, Togo, Cote d'ivore, Liberia, Benin Republic and Sierre Leone (Venette and Lason, 2004; Okon and lbom, 2012). It is often sought after because of its large size, distinct markings and nutritive value. It has a pattern of black wavy streaks on a yellowish background and can grow up to $30 \mathrm{~cm}$ in shell length and $25 \mathrm{~cm}$ in shell width (Cobbinah et al., 2008). The shells are conical in shape and fairly pointed than other snail species. In captivity under intensive management, it attains sexual maturity between 10 and 12 months and can lay between 30 and 300 eggs/clutch with diameter from 4 to $10 \mathrm{~cm}$ per egg (King, 2008). It is the most prized snail after Archachatina marginata for eating as it may weigh up to $500 \mathrm{~g}$ at maturity.

Achatina fulica (Plate 2), also called giant East African snail found in Africa, specifically in South of the Sahara in East Africa (Kenya and Tanzania), Liberia and Cote d'ivore (Venette and Larson, 2004; Okon and lbom, 2012). A. fulica is one of the smallest among the giant land snails of the world, growing with a long and greatly swollen body whorl (Jummai and Okoli, 2013). It has a narrow, conical shell being about twice as long as its width and contains 7 to 9 whorls when fully grown. The shell is generally reddish brown in colour with weak yellowish vertical markings but colouration varies with environmental conditions and diet. The adult $A$. fulica snail shell is about $7 \mathrm{~cm}$ in length and $20 \mathrm{~cm}$ or more in width. It produces large eggs that are 4.5 to $5.5 \mathrm{~cm}$ in diameter and only hatch at temperature of about $15^{\circ} \mathrm{C}$.

According to Okon and Ibom (2011), the quantitative measure of animal conformation is important as this will enable reliable parameters for a given trait to be estimated and therefore allow its inclusion in breeding programmes. While, Ibom (2009) opined that body weight and body parameters such as shell length, shell width, shell thickness, shell 'mouth' length and shell 'mouth' width are quantitative (morphometric) traits mostly used to measure snail growth and growth rate. In addition, Okon and lbom (2011) recommended morphometric (phenotypic) traits as good prediction tools of hatchling weights in juvenile and $\mathrm{F}_{1}$ crossbred of $A$. marginata snails. Besides, these authors opined that genetic improvement of any breed of snail in order to increase their contribution to the much needed animal protein in Nigeria is inevitable and could be achieved by estimate of genetic correlations among performance traits in the breeding objective and development of selection program for effective planning. There is dearth of information on phenotypic (morphometric) traits differentiation and phenotypic correlations of $A$. achatina and $A$. fulica as their survival and reproductive rates are slightly low in Nigeria. This study therefore aimed at providing the

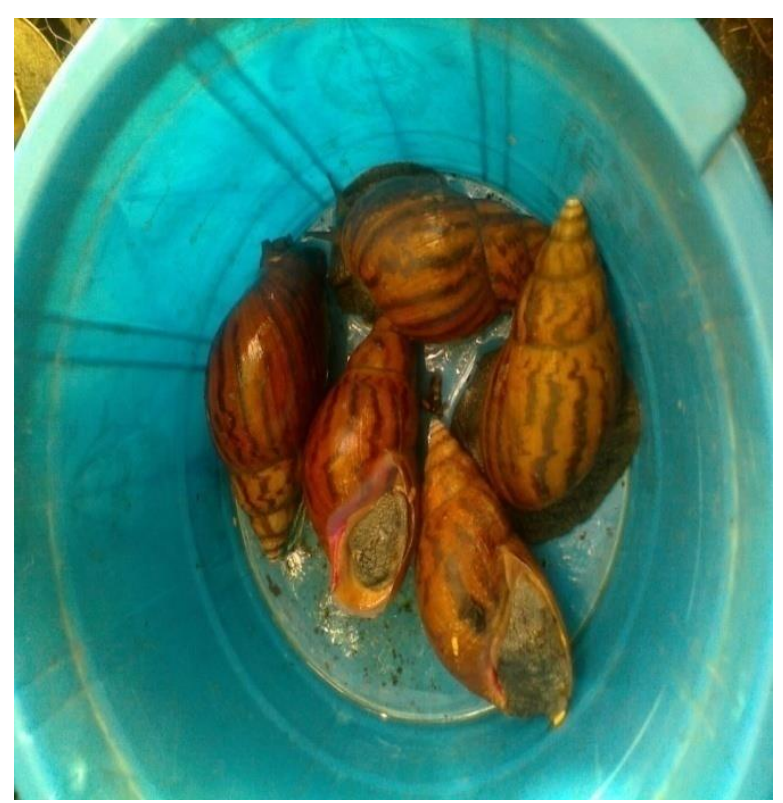

Plate 1. Achatina achatina.

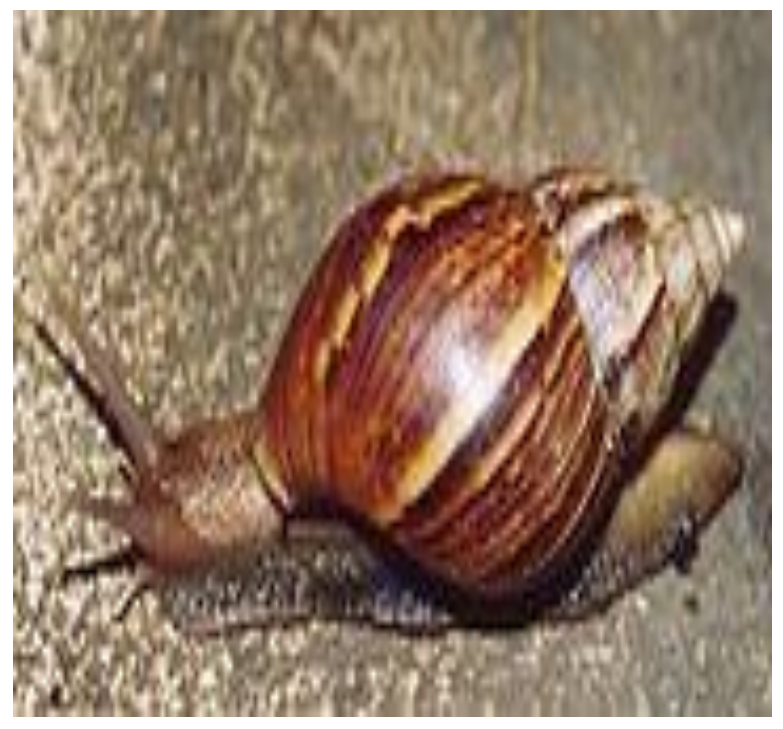

Plate 2. Achatina fulica.

scarce information on comparative morphometric (phenotypic) traits differentiation and phenotypic correlations between these two breeds of snails with 4 and 5 whorls.

\section{MATERIALS AND METHODS}

\section{Experimental site}

The research was carried out in Department of Animal Science, University of Calabar, Calabar, Nigeria. 


\section{Experimental Animals}

Four hundred (400) adult mature black-skinned snails, two hundred (200) each of Achatina achatina (Aa) and Achatina fulica (Af) were sourced from a reputable snail farmer in lbadan. The sorting was done using keys prescribed by Segun (1975) and Hodasi (1984). Identification of the snails into breeds (Achatina achatina and Achatina fulica was done using the profile and template of Nisbert (1974) and Rushton (2012) respectively.

Achatina achatina and Achatina fulica snails with four (4) whorls on the shell had body weight ranges from 83.00 to $180.50 \mathrm{~g}$ (average $156.90 \mathrm{~g}$ ) and from 30.60 to $85.20 \mathrm{~g}$ (average $49.70 \mathrm{~g}$ ) respectively. While $\mathrm{Aa}$ and Af snails with five (5) whorls on the shell had body weight ranges from 132.70 to $272.80 \mathrm{~g}$ (average $139.95 \mathrm{~g}$ ) and from 50.60 to $119.30 \mathrm{~g}$ (average $59.58 \mathrm{~g}$ ) respectively.

\section{Data collection}

Data measured on morphometric (phenotypic) traits from both breeds were body weight (BDW), shell length (SHL), shell width (SHW), Aperture length (APL), Aperture width (APW), Spiral length (SPL), Spiral width (SPW), diagonal length (DAL) and length between the aperture and first spiral (LAS).

The morphometirc (phenotypic) dimensional shell parameters were measured in millimeters $(\mathrm{mm})$ using Venier caliper, while the body weights (BDW) were measured in grammes $(\mathrm{g})$ using Scout $\mathrm{Pro}^{\circledR}$ electronic scale with a sensitivity of $0.01 \mathrm{~g}$. The dimensional shell parameters were taken as described by lbom (2009) and El. Zaffir et al. (2011).

\section{Statistical analysis}

The data obtained were analysed using GENSTAT (2011) software package for simple statistics (mean and standard error), t-test and phenotypic correlations, between body weights and other morphometric traits.

\section{RESULTS AND DISCUSSION}

The results of the description of sampled population were expressed as Mean \pm standard error of mean and paired sampled test for each morphometric measurement (Table 1). Achatina achatina snails with 4 and 5 whorls had higher values for all measured morphometric traits than Achatina fulica snails. There were large disparities which were significantly different $(p<0.001)$ between the mean body weights with number of whorls of these two breeds; $156.90 \mathrm{~g}$ for $A$. achatina, $49.70 \mathrm{~g}$ for $A$. fulica with 4 whorls while $138.95 \mathrm{~g}$ for $A$. achatina, $59.58 \mathrm{~g}$ for $A$. fulica with 5 whorls (Table 1). Similarly, all other measured morphometric traits of $A$. achatina snails 4 and 5 whorls were bigger and longer than those of $A$. fulicawith 4 and 5 whorls. The results indicated that $A$. achatina with 4 and 5 whorls are genetically heavier and larger than $A$. fulica with 4 and 5 whorls, as this was confirmed by the test of significance of the difference (t-test) between the two breads with 4 and 5 whorls (Table 1 ). The results agreed with the views of CAB (2003) and Venette and Larson (2004) that $A$. achatina is the largest snail among the giant African land snails and $A$. fulicathe smallest. Besides, the results also agreed with Okon et al. (2012) and Etukudo (2013) that snails with higher number of whorls weigh more and are heavier and larger than those with lower number of whorls.

On the other hand, the results of mean body weights (Table 1) in this study did not agree with the higher mean body weight (BDW) value of $138.60 \mathrm{~g}$ for $A$. fulica snails with 4 whorls by Okon et al. (2012). The BDW results were higher than the $127.20 \mathrm{~g}$ and $48.85 \mathrm{~g}$ for mean body weights for $A$. achatina and $A$. fulica snails with 4 whorls respectively reported recently by Etim (2017). The mean BDW of $182.00 \mathrm{~g}$ and $65.05 \mathrm{~g}$ for $A$. achatina and $A$. fulica snails with 5 whorls also reported by Etim (2017) were higher and heavier than the $138.95 \mathrm{~g}$ and $59.58 \mathrm{~g}$ for $A$. achatina and $A$. fulica snails with 5 whorls obtained in this study. Whereas, Etta et al. (2015) reported a higher mean BDW of $137.50 \mathrm{~g}$ for $A$. fulica snails with 4 whorls compared to very low mean BDW of $49.90 \mathrm{~g}$ for $A$. fulica snails with 4 whorls in this study. While, lbom et al. (2014) had earlier reported higher mean body weights of $93.70 \mathrm{~g}, 109.70 \mathrm{~g}$ and $73.00 \mathrm{~g}$ for A. fulica snails from central agro-ecological zone, northern agro-ecological zone and southern agro-ecological zone of Delta state respectively. But, further recorded low mean body weights of $120.90 \mathrm{~g}, 107.50 \mathrm{~g}$ and $72.00 \mathrm{~g}$ for A. achatina snails from central agro-ecological zone, northern agroecological zone and southern agro-ecological zone of Delta state compared to the higher and heavier results obtained for $A$. achatina snails here (Table 1). The difference in BDW here could be attributed to the age and size differences of snails used; body weight ranges as well as number of whorls on the shell of the snails. Ibom et al. (2014) used snails that were not classified into their different number of whorls, thus the variations in the mean BDW results.

On the other hand, morphometric traits measured as expressed large disparities which were significantly $(p<0.001)$ different between the mean shell parameters with number of whorls in these two breeds of snails (Table 1). The results obtained were higher and longer than the $10.440 \mathrm{~mm}, 5.087 \mathrm{~mm}, 5.291 \mathrm{~mm}, 2.990 \mathrm{~mm}$ for SHL, SHW, APL and APW for A. fulica with 4 whorls respectively reported by Etta et al. (2015).

The results of phenotypic correlations among morphometric traits of the two breeds evaluated (Tables $2 \mathrm{a}$ and $2 \mathrm{~b}$ ) indicated negative, weak, low and nonsignificant $(p>0.05)$ correlation coefficients $\left(r_{p}\right)$ between 
Table 1. Mean \pm SE and Paired Sampled Test of Morphometric Traits between Achatina achatina (Aa) and Achatina fulica (Af) snails with 4 and 5 whorls.

\begin{tabular}{|c|c|c|c|c|c|c|}
\hline $\begin{array}{l}\text { Morphometric } \\
\text { Traits }\end{array}$ & $\begin{array}{l}\text { No. of } \\
\text { whorls }\end{array}$ & $A A X \pm \overline{S E}$ & $A F X \pm \overline{S E}$ & $\begin{array}{c}\text { Paired morphometric } \\
\text { traits }\end{array}$ & t-values & $\begin{array}{c}\text { Significant } \\
\text { level }\end{array}$ \\
\hline \multirow{2}{*}{$\mathrm{BDW}(\mathrm{g})$} & 4 & $156.90 \pm 6.280$ & $49.70 \pm 3.430$ & AA-BDW/AF-BDW & 14.98 & $0.00 / * * *$ \\
\hline & 5 & $138.95 \pm 10.550$ & $59.58 \pm 2.330$ & AA-APL/AF-APL & 7.33 & $0.00 / * * *$ \\
\hline \multirow{2}{*}{ APL (cm) } & 4 & $5.078 \pm 0.070$ & $2.781 \pm 0.148$ & AA-APL/AF-APL & 16.22 & $0.00 / * \star \star$ \\
\hline & 5 & $4.763 \pm 0.139$ & $3.243 \pm 0.083$ & AA-APL/AF-APL & 9.74 & $0.00 / * \star *$ \\
\hline \multirow{2}{*}{$\mathrm{APW}(\mathrm{cm})$} & 4 & $1.820 \pm 0.050$ & $0.881 \pm 0.067$ & AA-APW/AF-APW & 10.40 & $0.00 / * * *$ \\
\hline & 5 & $1.732 \pm 0.088$ & $1.061 \pm 0.044$ & AA-APW/AF-APW & 7.63 & $0.00 / * * *$ \\
\hline \multirow{2}{*}{$\mathrm{SHL}(\mathrm{cm})$} & 4 & $10.122 \pm 0.158$ & $5.844 \pm 0.228$ & AA-SHL/AF-SHL & 14.75 & $0.00 / * \star \star$ \\
\hline & 5 & $9.258 \pm 0.259$ & $6.786 \pm 0.129$ & AA-SHL/AF-SHL & 9.52 & $0.00 / * * *$ \\
\hline \multirow{2}{*}{$\mathrm{SHW}(\mathrm{cm})$} & 4 & $4.332 \pm 0.076$ & $2.544 \pm 0.102$ & AA-SHW/AF-SHW & 12.98 & $0.00 / * * *$ \\
\hline & 5 & $4.063 \pm 0.130$ & $2.661 \pm 0.052$ & AA-SHW/AF-SHW & 10.09 & $0.00 / * * *$ \\
\hline \multirow{2}{*}{ SPL (cm) } & 4 & $2.244 \pm 0.96$ & $0.775 \pm 0.054$ & AA-SPL/AF-SPL & 13.35 & $0.00 / * * *$ \\
\hline & 5 & $1.979 \pm 0.073$ & $1.118 \pm 0.045$ & AA-SPL/AF-SPL & 10.28 & $0.00 / * * *$ \\
\hline \multirow{2}{*}{$\mathrm{SPW}(\mathrm{cm})$} & 4 & $1.046 \pm 0.070$ & $0.150 \pm 0.022$ & AA-SPW/AF-SPW & 12.15 & $0.00 / * \star \star$ \\
\hline & 5 & $0.705 \pm 0.052$ & $0.261 \pm 0.037$ & AA-SPW/AF-SPW & 6.74 & $0.00 / * \star \star$ \\
\hline \multirow{2}{*}{$\mathrm{DAL}(\mathrm{cm})$} & 4 & $3.159 \pm 0.063$ & $1.594 \pm 0.093$ & AA-DAL/AF-DAL & 13.50 & $0.00 / * * *$ \\
\hline & 5 & $2.947 \pm 0.110$ & $1.802 \pm 0.043$ & AA-DAL/AF-DAL & 9.71 & $0.00 / * * *$ \\
\hline \multirow{2}{*}{ LAS (cm) } & 4 & $7.173 \pm 0.123$ & $4.363 \pm 0.121$ & AA-LAS/AF-LAS & 16.34 & $0.00 / * * *$ \\
\hline & 5 & $6.574 \pm 0.206$ & $4.702 \pm 0.089$ & AA-LAS/AF-LAS & 9.52 & $0.00 / * \star *$ \\
\hline
\end{tabular}

$\mathrm{AA}=$ Achatina achatina, $\mathrm{AF}=$ Achatina fulica, $\mathrm{BDW}=$ Body weight, $\mathrm{APL}=$ Aperture length, $\mathrm{APW}=\mathrm{Aperture}$ width, $\mathrm{SHL}=\mathrm{Shell}$ length, $\mathrm{SHW}=\mathrm{Shell}$ width, $\mathrm{SPL}=$ Spiral length, SPW $=$ Spiral width, $\mathrm{DAL}=$ Diagonal length and $\mathrm{LAS}=$ Length between the aperture and first spiral. ${ }^{\star \star \star} \mathrm{P}<0.001(\mathrm{Highly}$ Significant).

Table 2a. Phenotypic coefficient of correlation $\left(r_{p}\right)$ of morphometric traits between Achatina achatina and Achatina fulica snails with 4 whorls.

\begin{tabular}{lccccccccc}
\hline Parameters & BDW & SHL & SHW & APL & APW & SPL & SPW & DAL & LAS \\
\hline BDW & 1.000 & $-0.362^{N S}$ & $-0.041^{N S}$ & $-0.434^{*}$ & $0.259^{N S}$ & $0.156^{N S}$ & $0.226^{N S}$ & $0.026^{N S}$ & $0.223^{N S}$ \\
SHL & $-0.581^{*}$ & 1.000 & $-0.124^{N S}$ & $0.011^{N S}$ & $0.094^{N S}$ & $-0.030^{N S}$ & $-0.350^{N S}$ & $-0.152^{N S}$ & $-0.658^{* *}$ \\
SHW & $-0.621^{* *}$ & $0.273^{N S}$ & 1.000 & $-0.355^{N S}$ & $-0.479^{N S}$ & $-0.068^{N S}$ & $0.254^{N S}$ & $-0.227^{N S}$ & $0.090^{N S}$ \\
APL & $-0.060^{N S}$ & $-0.639^{* *}$ & $0.163^{N S}$ & 1.000 & $0.210^{N S}$ & $0.125^{N S}$ & $-0.013^{N S}$ & $-0.034^{N S}$ & $-0.480^{N S}$ \\
APW & $0.420^{N S}$ & $-0.091^{N S}$ & $-0.657^{* *}$ & $-0.190^{N S}$ & 1.000 & $0.338^{N S}$ & -0.001 & $0.012^{N S}$ & $-0.430^{N S}$ \\
SPL & $0.187^{N S}$ & $-0.195^{N S}$ & $-0.141^{N S}$ & $-0.024^{N S}$ & $0.191^{N S}$ & 1.000 & $-0.303^{N S}$ & $-0.205^{N S}$ & $-0.222^{N S}$ \\
SPW & $0.239^{N S}$ & $-0.284^{N S}$ & $0.183^{N S}$ & $-0.002^{N S}$ & $0.370^{N S}$ & $-0.368^{N S}$ & 1.000 & $0.066^{N S}$ & $0.063^{N S}$ \\
DAL & $0.339^{N S}$ & $0.013^{N S}$ & $-0.578^{*}$ & $-0.090^{N S}$ & $0.193^{N S}$ & $-0.213^{N S}$ & $-0.220^{N S}$ & 1.000 & $-0.020^{N S}$ \\
LAS & $-0.547^{*}$ & $0.084^{N S}$ & $0.020^{N S}$ & $0.016^{N S}$ & $-0.169^{N S}$ & $-0.165^{N S}$ & $0.003^{N S}$ & $-0.370^{N S}$ & 1.000 \\
\hline
\end{tabular}

$\mathrm{BDW}=$ Body weight, $\mathrm{SHL}=$ Shell length, $\mathrm{SHW}=$ Shell width, $\mathrm{APL}=$ Aperture length, $\mathrm{APW}=$ Aperture width, $\mathrm{SPL}=\mathrm{Spiral}$ length, $\mathrm{SPW}=\mathrm{Spiral}$ width, $\mathrm{DAL}=$ Diagonal length, LAS $=$ Length between the aperture and first spiral, NS $=P>0.05$ (N. Significant level), $\quad * *=P<0.01($ High significant level), ${ }^{*}=\mathrm{P}<0.05$ (Lower significant level).

body weights and most shell components studied for $A$. achatina and $A$. fulica snails with 4 and 5 whorls. There was only one negative, highly significant $(p<0.01)$ phenotypic correlation coefficient $(r=-0.658)$ between SHL and LAS for $A$. achatina snail with 4 whorls in this study (Table 2a). Also, there were very few negative, highly significant $(p<0.01)$ phenotypic correlation coefficients $\left(r_{p}\right)$ between BDW and SHW $(r=-0.621)$, APL and SHL $(r=-0.639), A P W$ and SHW $(r=-0.657)$ for $A$. fulica snails with 4 whorls. Most of the non- significant $(p>0.05)$ phenotypic correlation coefficients obtained in this study (Table $2 \mathrm{a}$ and $2 \mathrm{~b}$ ) denoted that these pairs of traits have no direct relationship and are likely not controlled by the same genes in the same direction. The only positive, but low, non-significant ( $p>0.05)$ phenotypic correlation coefficient obtained for Achatina fulica snails with 4 whorls was between BDW and APW $(r=0.420)$, whereas that for A. achatina with 5 whorls was between BDW and APW $(r=0.529)$, and between SPW and APW $(r=0.550)$ respectively. The 
Table 2b. Phenotypic coefficient of correlation $\left(r_{p}\right)$ of Morphometric traits between Achatina achatina and Achatina fulica snails with 5 whorls.

\begin{tabular}{lccccccccc}
\hline Parameters & BDW & SHL & SHW & APL & APW & SPL & SPW & DAL & LAS \\
\hline BDW & 1.000 & $-0.500^{*}$ & $-0.163^{\mathrm{NS}}$ & $-0.613^{* *}$ & $0.529^{*}$ & $0.352^{\mathrm{NS}}$ & $-0.001^{\mathrm{NS}}$ & $0.439^{\mathrm{NS}}$ & 0.271 \\
SHL & $-0.359^{\mathrm{NS}}$ & 1.000 & $-0.335^{\mathrm{NS}}$ & $0.314^{\mathrm{NS}}$ & $0.090^{\mathrm{NS}}$ & $-0.549^{*}$ & $0.003^{\mathrm{NS}}$ & $-0.375^{\mathrm{NS}}$ & $-0.641^{* *}$ \\
SHW & $-0.252^{\mathrm{NS}}$ & $-0.226^{\mathrm{NS}}$ & 1.000 & $-0.300^{\mathrm{NS}}$ & $0.602^{* *}$ & $-0.059^{\mathrm{NS}}$ & $0.248^{\mathrm{NS}}$ & $-0.142^{\mathrm{NS}}$ & $0.089^{\mathrm{NS}}$ \\
APL & $0.188^{\mathrm{NS}}$ & $-0.243^{\mathrm{NS}}$ & $-0.298^{\mathrm{NS}}$ & 1.000 & $-0.264^{\mathrm{NS}}$ & $-0.181^{\mathrm{NS}}$ & $-0.027^{\mathrm{NS}}$ & $-0.312^{\mathrm{NS}}$ & $-0.325^{\mathrm{NS}}$ \\
APW & $-0.068^{\mathrm{NS}}$ & $-0.067^{\mathrm{NS}}$ & $0.113^{\mathrm{NS}}$ & $0.136^{\mathrm{NS}}$ & 1.000 & $0.146^{\mathrm{NS}}$ & $0.550^{*}$ & $0.275^{\mathrm{NS}}$ & $-0.133^{\mathrm{NS}}$ \\
SPL & $0.467^{\mathrm{NS}}$ & $-0.489^{\mathrm{NS}}$ & $0.076^{\mathrm{NS}}$ & $0.271^{\mathrm{NS}}$ & $0.088^{\mathrm{NS}}$ & 1.000 & $-0.318^{\mathrm{NS}}$ & $0.368^{\mathrm{NS}}$ & $0.108^{\mathrm{NS}}$ \\
SPW & $0.323^{\mathrm{NS}}$ & $-0.070^{\mathrm{NS}}$ & $0.088^{\mathrm{NS}}$ & $-0.003^{\mathrm{NS}}$ & $-0.095^{\mathrm{NS}}$ & $-0.343^{\mathrm{NS}}$ & 1.000 & $-0.354^{\mathrm{NS}}$ & $0.219^{\mathrm{NS}}$ \\
DAL & $0.307^{\mathrm{NS}}$ & $0.035^{\mathrm{NS}}$ & $0.079^{\mathrm{NS}}$ & $-0.401^{\mathrm{NS}}$ & $-0.334^{\mathrm{NS}}$ & $-0.346^{\mathrm{NS}}$ & $0.046^{\mathrm{NS}}$ & 1.000 & $-0.074^{\mathrm{NS}}$ \\
LAS & $-0.141^{\mathrm{NS}}$ & $-0.605^{* *}$ & $-0.135^{\mathrm{NS}}$ & $0.002^{\mathrm{NS}}$ & $-0.078^{\mathrm{NS}}$ & $-0.093^{\mathrm{NS}}$ & $0.025^{\mathrm{NS}}$ & 0.007 & 1.000 \\
\hline
\end{tabular}

$\mathrm{BDW}=$ Body weight, $\mathrm{SHL}=$ Shell length, $\mathrm{SHW}=$ Shell width, $\mathrm{APL}=$ Aperture length, $\mathrm{APW}=$ Aperture width, $\mathrm{SPL}=\mathrm{Spiral}$ length $\mathrm{SPW}=$ Spiral width, $\mathrm{DAL}=$ Diagonal length, $\mathrm{LAS}=$ Length between the aperture and first spiral, NS $=\mathrm{P}>0.05$ (N. Significant level), ${ }^{\star \star}$ $=\mathrm{P}<0.01$ (High significant level), ${ }^{*}=\mathrm{P}<0.05$ (Lower significant level).

only highly positive, significant phenotypic correlation coefficient of $r=0.602$ was obtained between APW and $\mathrm{SHW}$ for the snails with 5 whorls. This, according to lbom (2009) and Okon et al. (2011) signifies that the pairs of morphometric trait used have direct relationship or at least they are controlled by the same gene in the same direction, thus selection for one trait will lead to improvement of the others. The results corroborated Ehiobu and Kyado (2000) and Ibom (2009) views that correlations between morphometric traits could be high or low, positive or negative. On the other hand, these results of negative, low, non-significant phenotypic correlations between the body weights and most of the shell parameters studied disagreed with Okon et al. (2010a, b) and Okon et al. (2011) earlier views of high correlated responses of these morphometric traits for selection and cross breeding for genetic improvement. The differences in correlation coefficients could be attributed to breed effect, age and size differences of snails used, body weight ranges as well as number of whorls on the shell of the snails. Most of the authors cited in literature had use A. marginata either at juvenile or growing phases without separating them into their ages and number of whorls. In other words, breed type and number of whorls on shell of the snails used have high effects on phenotypic correlation coefficient $\left(r_{p}\right)$ estimates.

However, the results obtained currently are quite lower than the positive, strong, highly significant $(p<0.001)$ correlation coefficient of $r=0.988$ reported by lbom et al. (2016) for pairs of SHL and SHW, SHL and APW of offspring of heterozygous mating between $A$. marginata var. ovum (BO) and $A$. marginata var. saturalis (BS), and also positive, strong, highly significant $(p<0.001)$ correlation coefficients $r=0.977$ between BDW and SHW, $r=0.961$ between BDW and APL, $r=0.954$ between BDW and APW of offspring of heterozygous mating between BS $x$ BS. Okon et al. $(2010 a$, b) had earlier reported strong, positive and highly significant correlation coefficient of $r=0.96$ between hatchlings body weight (BDW) and shell length (SHL) for the purebred white-skinned (Albino) and $\mathrm{F}_{1}$, crossbred snails of $A$. marginata. Similarly, Sam et al. (2016) recently reported strong, positive and highly significant correlation coefficient of $r=0.711$ between BDW and SHW for blackskinned $A$. marginata and $r=0.827$ between BDW and SHW for white-skinned $A$. marginata. Whereas, Etta et al. (2015) noticed strong, positive, medium phenotypic correlation coefficients of $r=0.717$ between BDW and BSL, $r=0.674$ between BDW and BSW, $r=0.618$ between BSL and SML for Achatina fulica snails. The differences in correlation coefficients could be attributed to earlier reasons of breed effect, age and sizes differences of snails used; body weight ranges as well as number of whorls on the shell of snails. Besides, it might also be due to the fact that $A$. marginata snails used by most of the authors cited is mainly a terrestrial snails, whereas $A$. achtina and $A$. fulica snails are mostly associated with tropical and sub-tropical moist broadleaf forest (Venette and Larson, 2004), typical of Ibadan where the snails were collected. Again, the size and wider spread of the body weight range of $A$. achatina than those of $A$. fulica snail. $A$. achatina and $A$. fulica snails with 4 whorls used for the study had higher and wider body weights ranges from 83.00 to $180.50 \mathrm{~g}$ (Averages $156.90 \mathrm{~g}$ ) and from 30.60 to $85.20 \mathrm{~g}$ (Average $49.70 \mathrm{~g})$ respectively. While $A$. achatina and $A$. fulica snails with 5 whorls had body weight ranges from 132.70 to $272.80 \mathrm{~g}$ (Average $138.95 \mathrm{~g}$ ) and from 50.60 to 119.30 $\mathrm{g}$ (Average $59.58 \mathrm{~g}$ ) respectively. Besides, the snails used here had 4 and 5 whorls as against other studies with or without varied number of whorls, age and size differences. But Venette and Larson (2004) opined that full-grown snails have between 7 and 9 whorls. Again, $A$. achatina is the largest gastropod among giant African land snails and $A$. fulica is known to be the smallest (CAB, 2003; Venette and Larson, 2004). 


\section{Conclusion}

Achatina achatina snails with 4 and 5 whorls had higher values than Achatina fulica for all measured morphometric traits. There were high disparities which were significantly different $(P<0.001)$ between BDW and all morphometric traits of snails with 4 and 5 whorls. Achatina achatina snails with 4 and 5 whorls were genetically heavier and larger than Achatina fulica with 4 and 5 whorls as confirmed by the test of significance of the difference (t-test). The phenotypic correlations among morphometric traits of the two breeds were negative, weak and of low significant $(P<0.05)$ and non-significant $(P>0.05)$ correlation coefficient $\left(r_{p}\right)$ between BDW and most shell components studied. These revealed that breed type, age and size differences of snails used, body weight ranges and numbers of whorls on snail shells have high effects on morphometric traits differentiation and correlation coefficient estimates. Thus, the morphometirc traits of the two breeds of snails studied could be chosen to differentiate as well as characterize snails.

\section{CONFLICT OF INTEREST}

The authors declare that they have no conflict of interest.

\section{REFERENCES}

CAB (2003). Crop protection compendium: Global module. Commonwealth Agricultural Bureau International, Wallingford, UK.

Cobbinah, J. R., Vink, A., \& Onwuka, B. (2008). Snail Farming. CTA Agrodok Series No. 47. p.78.

Ehiobu, N. G., \& Kyado, J. A. (2000). Heritability, Repeatability and Genetic Correlation of Swine. Proceedings of the $25^{\text {th }}$ Annual Conference of Nigerian Society for Animal Production (NSAP). March 19 - 22, 2000, Umudike, Nigeria, Pp. 260261.

El. Zaffir, B., El sheik, E. O., \& Zuhier, N. M. (2011). Some Linear Measurements of Bulinus truncates Snails collected from Water Bodies of Two Agricultural Schemes in Khantoun State, Sudan, University of African Journal of Science (UAJS). 1(1), 35-43.

Etim, A. B. (2017). Phenotypic traits differentiation, identification of Chromosome Numbers and Body Weights Prediction among Three breeds of Snails and Two varieties of Archachatina marginata Snails. M. Sc. Thesis, Department of Animal Science, University of Calabar, Calabar, Nigeria, p. 211

Etta, H. E., Okon, E. A., \& Ekpe, P. A. (2015). Comparative Phenotypic Assessment of two Snail Breeds Archachatina marginata (S) and Achatina fulica (L) in Calabar, Cross River State. Proceedings of $4^{\text {th }}$ International Conference/Workshop on Giant African Land Snails (NetGALS) $1^{\text {st }}-4^{\text {th }}$ June, 2015, Nnamdi Azikiwe University, Awka. Pp. 40-48.

Etukudo, O. M. (2013). Developmental stages of eggs, phenotypic and genetic characterization of two Ectotypes of
Giant African Land Snails (Archachatina marginata var. Saturaliś). M. Sc. Thesis. Department of Genetics and Biotechnology, University of Calabar, Nigeria, Pp. 1-97.

Genstat (2011). Genstat Release 10.3 DE (PC/Windows 7), VSN International Ltd (Rothansted Experimental Station).

Hodasi, J. K. M. (1984). Some Aspects of the Biology of Achatina achatina (Linne). Journal of Molluscan Studies, 48, 105-113.

Ibom, L. A. (2009). Variations in Reproductive and Growth Performance Traits of White-skinned $x$ black-skinned African Giant Snail Hatchlings (Archachatina marginata (Swainson) in Obubra, Nigeria. Ph. D. Thesis. Department of Animal Science, University of Calabar, Calabar, Nigeria, p. 166.

Ibom, L. A., Okon, B., \& Patani, I. (2016). Phenotypic correlations among Growth traits of Archachatina marginata Snails offspring in Calabar, Nigeria. Proceedings of the $5^{\text {th }}$ International Conference/Workshop on Giant African Land Snails (NetGALS), $5^{\text {th }}-9^{\text {th }}$ June, 2016, Calabar, Nigeria, Pp. 23-26.

Ibom, L. A., Okon, B., Okon, F. I., \& Nwambam, I. U. (2014). Morphological characterization of Giant African Land Snails from three Agro-ecological zones of Delta States. Proceedings of $3^{\text {rd }}$ International Conference/Workshop on Giant African Land Snail (NetGALS), $1^{\text {st }}-4^{\text {th }}$ June, 2014, Abeokuta, Nigeria, Pp. 38-44.

Jummai, A. T., \& Okoli, B. J. (2013). Compositional evaluation of Giant East African Snail. Research Journal in Engineering and Applied Science, 2(5), 391-401.

King, P. (2008). Identifying your snail. Website: www.petsnails.co.uk. Assessed $2^{\text {nd }}$ January, 2017.

Nisbert, R. N. (1974). The Life of Achatinidae in London. Proceedings of the Malacological Society of London, 41, 1171.

Nwankwo, C., \& Onwurah, F. B. (2015). Entrepreneurial Snail Farming: The Way Forward. Proceedings of the $4^{\text {th }}$ International Conference/Workshop on Giant African Land Snails (NetGALS), $1^{\text {st }}-4^{\text {th }}$ June, 2015, Nnamdi Azikiwe University, Akwa, Pp. 71-74.

Okon, B. \& Ibom, L. A. (2012). Snail Breeding and Snailery Management, Freshdew Production, Calabar, Nigeria. p. 90.

Okon, B., \& lbom, L. A. (2011). Phenotypic Correlation and Body Weights Prediction using Morphometric Traits of Snails in Calabar, Nigeria. Ethiopian Journal of Environmental Studies and Management, 4(3), 7-11.

Okon, B., Ibom, L. A., \& Odido, E. E. (2011). Reproductive Performance and Egg Quality Traits of Crossbreeding between Two Strains of Snails. Archivos De Zootecnia, 60(229), 153-156.

Okon, B., Ibom, L. A., Ettah, H. E., \& Ukpuho, I. E. (2012). Effects of Genotype, Dietary Protein and Energy on the Reproductive and Growth Traits of Parents and $F_{1}$, Hatchlings of Achatina achatina (L) Snails in Nigeria. International Journal of Applied Science and Technology, 2(1), 179-185.

Okon, B., Ibom, L. A., Williams, M. E., \& Akwa, N. T. (2010a). Parity Effects on Breeding and Morphometric Traits of Eggs and Hatchlings of Purebred Albino Snails [Archachatina marginata (Swainson)]. Journal of Agriculture, Biotechnology and Ecology, 3(1), 44-54.

Okon, B., Ibom, L. A., Williams, M. E., \& Etukudo, O. M. (2010b). Effects of Parity on Breeding and Morphometric Traits of Eggs and Hatchlings of $F_{1}$, Crossbred of Snails (Archachatina marginata var. saturaliś). Journal of Agriculture, Biotechnology and Ecology, 3(1), 36-43.

Rushton, J. (2012). Species General Information. 
http://www.petsnail.co.uk. Accessed $2^{\text {nd }}$ January, 2017.

Sam, I. M., Okon, B., Edem, W., \& Ukpanah, U. A. (2016). Quantitative traits measurements as predictor of body weight in black-skinned and white-skinned Archachatina marginata. Proceedings of the $5^{\text {th }}$ International Conference/Workshop on Giant African Land Snails (NetGALS), $5^{\text {th }}-9^{\text {th }}$ June, 2016, Calabar, Nigeria, Pp. 97-102.
Segun, A. O. (1975). The Giant Land Snail, Archachatina (Calachatina) marginata (Swainson). Benin City. Ethiope Publishing House, p. 68.

Venette, R. C., \& Larson, M. (2014). Mini risk assessment, giant African snail, Achatina fulica (Bowdich) (Gastrops: Achatinidae), Department of Entomology, University of Minnesota, St. Paw, MN55108, Pp. 1-30. 